\title{
The Danish Nephrology Registry
}

This article was published in the following Dove Press journal:

Clinical Epidemiology

25 October 2016

Number of times this article has been viewed

\section{James Heaf}

Department of Medicine, Roskilde Hospital, University of Copenhagen, Roskilde, Denmark
Correspondence: James Heaf Department of Medicine, Roskilde Hospital, Koegevej 7-I3, 4000 Roskilde, Denmark

Tel +45 42944 I I6

Email heaf@dadlnet.dk
Aim of database: The Danish Nephrology Registry's (DNR) primary function is to support the Danish public health authorities' quality control program for patients with end-stage renal disease in order to improve patient care. DNR also supplies epidemiological data to several international organizations and supports epidemiological and clinical research.

Study population: The study population included patients treated with dialysis or transplantation in Denmark from January 1, 1990 to January 1, 2016, with retrospective data since 1964.

Main variables: DNR registers patient data (eg, age, sex, renal diagnosis, and comorbidity), predialysis specialist treatment, details of eight dialysis modalities (three hemodialysis and five peritoneal dialysis), all transplantation courses, dialysis access at first dialysis, treatment complications, and biochemical variables. The database is complete $(<1 \%$ missing data). Patients are followed until death or emigration.

Descriptive data: DNR now contains 18,120 patients, and an average of 678 is added annually. Data for each transplantation course include donor details, tissue type, time to onset of graft function, and cause of graft loss. Registered complications include peritonitis in peritoneal dialysis patients, causes of peritoneal dialysis technique failure, and transplant rejections. Fifteen biochemical variables are registered, mainly describing anemia control, mineral and bone disease, nutritional and uremia status. Date and cause of death are also included. Six quality indicators are published annually, and have been associated with improvements in patient results, eg, a reduction in dialysis patient mortality, improved graft survival, and earlier referral to specialist care. Approximately, ten articles, mainly epidemiological, are published each year.

Conclusion: DNR contains a complete description of end-stage renal disease patients in Denmark, their treatment, and prognosis. The stated aims are fulfilled.

Keywords: dialysis, transplantation, epidemiology, kidney, uremia

\section{Introduction}

The Danish Nephrology Registry (DNR) was established on January 1, 1990 to provide a complete description of patients receiving active treatment for end-stage renal disease (ESRD) in Denmark. Available retrospective data since 1964 were included. The database has been nearly complete since 1990. A comparison with the Danish National Patient Registry (DNPR), using the gold standard of delivered dialysis for more than 3 months, has previously shown $<1 \%$ missing patient data. ${ }^{1}$ Transplantation activity is compared with data from Scandiatransplant, the Scandinavian organ allocation organization, and is therefore $100 \%$ complete. 
The stated aims of DNR are the following:

1. To fulfill the Danish public health authorities' requirements for clinical quality control for patients with ESRD. This involves benchmarking of hospitals, identification of departments with breach in treatment quality, and identification of risk factors for poor prognosis.

2. To fulfill the formal requirements of the European Renal Association-European Dialysis and Transplant Association (ERA-EDTA) for data reports of ESRD treatment in Denmark (these results are published annually in the ERA-EDTA Registry Annual Report).

3. To act as a data resource for scientific research, primarily epidemiological.

4. To produce yearly reports concerning quality indicator results and epidemiological analyses of interest for members of the Danish Society of Nephrology (DNS).

5. To supply the following international organizations with aggregated data concerning ESRD treatment in Denmark: the Organization for Economic Co-operation and Development (OECD), the World Health Organization (WHO), Eurostat, and the United States Renal Data Service (USRDS).These data are exported via ERA-EDTA.

\section{Study population}

All patients resident in Denmark who have been treated with maintenance hemodialysis (HD), peritoneal dialysis (PD), or renal transplantation (RT) from January 1, 1990 to January 1, 2016 are included. At present, the database contains 18,120 patients (January 1, 2016) and 678 new patients are added each year (average for the years 2010-2014). Retrospective data since 1964 are included, but many of these patients are missing. However, full clinical details of all patients who were prevalent on January 1, 1990 are available. We have complete follow-up on all patients included in the database until death, emigration, or other clinically relevant outcome. Patient registration completeness is compared with the registration in the DNPR. The details concerning the DNR organizational structure is given in Figure 1.

\section{Main variables}

Data are primarily entered manually into the database by the 15 Danish nephrology departments. The patients with ESRD are not treated at private hospitals or clinics. Comorbidity data are imported from the DNPR and transplant data from the Scandiatransplant database. Biochemical data are imported from the regional biochemistry departments.

\section{Patient data}

The registry contains the following patient data: name, civil personal registration number, age, sex, date of first consultation of nephrologist, and renal diagnosis, using the ERA-EDTA coding system, which can be mapped to the International Classification of Disease, tenth edition (ICD-10) and the Systematized Nomenclature of Medicine. The DNPR has registered the information regarding all inand outpatient diagnoses (ICD-8, now ICD-10) since 1977. The database collects this information in order to calculate the Charlson Comorbidity Index $(\mathrm{CCI})^{2}$ on the first ESRD treatment day and the first day of each transplantation. For any given patient and date, the CCI can be generated using all previously registered relevant primary and secondary ICD-10 codes. The date and cause of death are observed, using both the ERA-EDTA coding system and the three primary ICD-10 codes imported from the Civil Registration System.

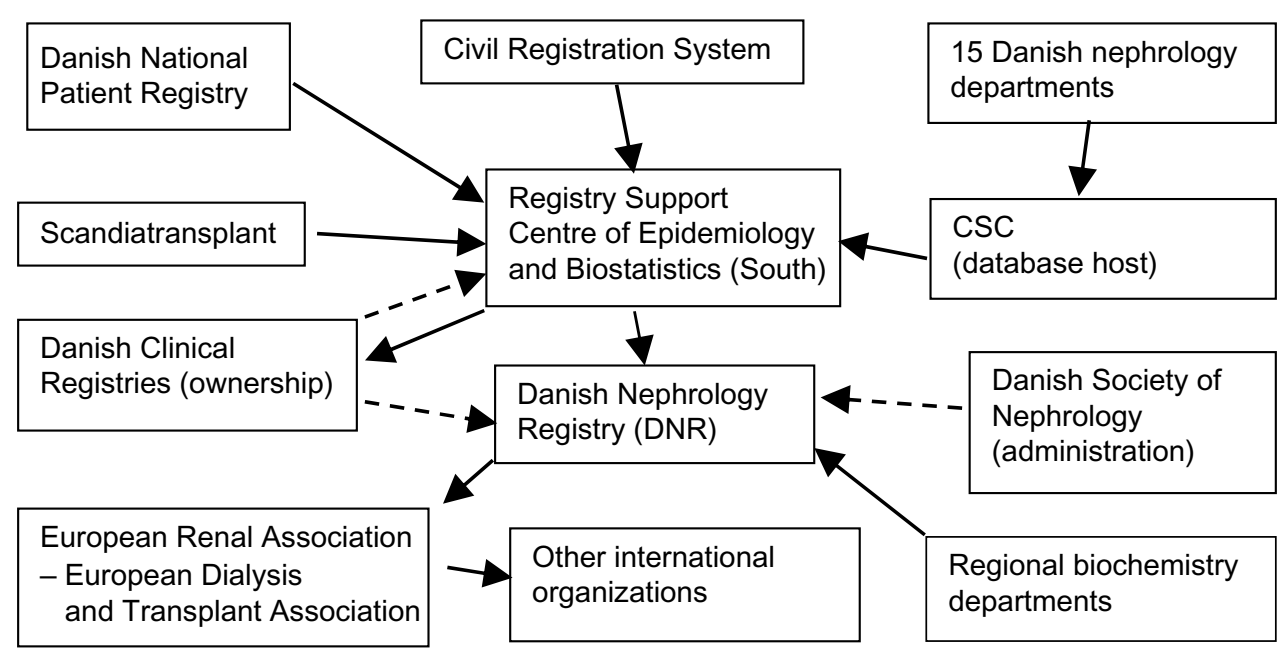

Figure I DNR organization.

Notes: Solid lines: data transfer; dotted lines: other specified relationship. 
The date of death is cross-checked with DNPR to achieve $100 \%$ data completeness. At any point in time, the patient will either be treated at one of the 15 national centers or abroad. Dates and center name of every transfer are recorded.

\section{Dialysis data}

Six types of primary dialysis access are registered, which define whether dialysis initiation is planned or unplanned.

Planned:

1. Arteriovenous fistula or graft

2. Tunneled venous catheter as the patient's permanent access

3. PD catheter placed more than 6 days before dialysis initiation.

Unplanned:

1. Temporary nontunneled venous catheter

2. Tunneled venous catheter as a temporary access

3. PD catheter placed 0-6 days before dialysis initiation Arteriovenous grafts are rarely used in Denmark.

The patient will often switch between several dialysis modalities during his/her life. The date of initiation of each of the following dialysis modalities is registered: HD, limited care $\mathrm{HD}$, home $\mathrm{HD}$, continuous ambulatory PD (CAPD), automated PD (APD), in-hospital APD, and combined HD and PD. Assisted PD (either CAPD or APD), defined as professional assistance in the home, is also observed.

Two complications of PD are included: dates of each peritonitis episode and cause of PD treatment termination. The possible causes for termination are transplantation, peritonitis, ultrafiltration failure, inadequate dialysis, hernia, abdominal operation, catheter problems, medical problems, patient choice, and social reasons.

The complications associated with HD are not included at present, but date and culture result of each bacteremia episode is noted.

\section{Transplantation data}

For each RT, the following data are included: date, transplant center (Rigshospitalet, Odense University Hospital, Aarhus University Hospital, or abroad), CCI at transplantation, tissue type (A, B, DR), and donor details (deceased or living). Living donors are classified as parents; identical twins; siblings with 0,1 , and 2 common haplotypes, respectively; other family; or nonrelated. The date of onset of graft function is defined as the date of last dialysis treatment. Date and cause of graft loss are observed: hyperacute rejection, rejection with or without immunosuppressive treatment, recurrent primary renal disease, operative problem, thrombosis, infection, removal of functioning graft, primary nonfunction, or unknown. All acute rejections are recorded with Banff diagnosis (borderline, 1, 1B, 2A, 2B, 3, antibody-mediated).

\section{Biochemical data}

Biochemical data are important for benchmarking and identifying risk factors for poor prognosis. The following blood or plasma biochemical data are imported from the regional biochemistry departments: hemoglobin, iron, transferrin, transferrin saturation, ferritin, C-reactive protein, ionized calcium, phosphate, parathyroid hormone, 25-hydroxycholecalciferol, albumin, creatinine, urea, bicarbonate, total cholesterol, low-density lipoprotein (LDL) cholesterol, high-density lipoprotein (HDL) cholesterol, and triglycerides. Biochemical registration was introduced in 2000 . Initially, only three variables (hemoglobin, creatinine, and albumin) were included, the present dataset being introduced in 2008. For historical reasons, only one value for each patient is recorded for each year, being the first value of the day that is closest to November 1 of that year. Data completeness is shown in Table 1.

\section{Quality indicators}

Indicator results have been published since 1990, and were formalized in 2000 . The database currently produces six center-specific quality indicators yearly for Danish Regions

Table I Biochemical data completeness in 2014

\begin{tabular}{|c|c|c|c|}
\hline Variable & $\begin{array}{l}\text { Hemodialysis } \\
\text { (\%) }\end{array}$ & $\begin{array}{l}\text { Peritoneal } \\
\text { dialysis (\%) }\end{array}$ & $\begin{array}{l}\text { Renal } \\
\text { transplantation } \\
(\%)\end{array}$ \\
\hline Hemoglobin & 93 & 93 & 87 \\
\hline Albumin & 93 & 94 & 87 \\
\hline Bicarbonate & 53 & 55 & 43 \\
\hline Calcium & 89 & 91 & 84 \\
\hline Total cholesterol & 55 & 62 & 43 \\
\hline HDL cholesterol & 50 & 54 & 37 \\
\hline LDL cholesterol & 48 & 46 & 36 \\
\hline C-reactive protein & 92 & 91 & 76 \\
\hline Creatinine & 94 & 91 & 87 \\
\hline Ferritin & 81 & 84 & 40 \\
\hline Iron & 78 & 84 & 24 \\
\hline $\begin{array}{l}\text { Parathyroid } \\
\text { hormone }\end{array}$ & 79 & 82 & 44 \\
\hline Phosphate & 92 & 93 & 85 \\
\hline Transferrin & 78 & 87 & 23 \\
\hline $\begin{array}{l}\text { Transferrin } \\
\text { saturation }\end{array}$ & 77 & 86 & 23 \\
\hline Triglyceride & 52 & 50 & 41 \\
\hline Urea & 93 & 94 & 90 \\
\hline Vitamin D & 67 & 47 & 25 \\
\hline
\end{tabular}

Abbreviations: HDL, high-density lipoprotein; LDL, low-density lipoprotein. 
and for the clinicians treating the patients, in order for them to improve the clinical care. Quality indicators are chosen after consultation with Danish Regions, the DNR board of directors, and the nephrological departments. Indicators are regularly revised to identify areas where treatment improvement may be possible. A further indicator (incidence of bacteremia) is planned, as is correction of mortality indicators for patient age and morbidity. Details are shown in Table 2.
Analyses of quality indicators, benchmarking, quality audit, and feedback to departments are a mandatory part of annual reports. Publication of these quality indicator reports is necessary for database approval.

In addition, seven center-specific biochemical quality indicator results for dialysis patients are published (Table 2). Results for transplant patients are also published but there are no defined quality indicators for these.

Table 2 Quality indicators: all indicators are published yearly

\begin{tabular}{|c|c|c|c|c|c|c|}
\hline Indicator & Definition & Population & Format & Standard & $\begin{array}{l}\text { Patient exclusion } \\
\text { criteria }\end{array}$ & $\begin{array}{l}\text { Indicator } \\
\text { type }\end{array}$ \\
\hline \multicolumn{7}{|c|}{ Danish Regions quality indicators } \\
\hline $\begin{array}{l}\text { I) Planned dialysis } \\
\text { initiation }\end{array}$ & $\begin{array}{l}\text { Planned: } \\
\text { Dialysis initiation using either } \\
\text { I) Arteriovenous fistula or graft } \\
\text { 2) Tunneled venous access } \\
\text { as the patient's permanent } \\
\text { access } \\
\text { 3) PD catheter installed }>6 \\
\text { days before start of dialysis }\end{array}$ & $\begin{array}{l}\text { Incident patients } \\
\text { treated with dialysis } \\
\text { as their initial } \\
\text { treatment modality }\end{array}$ & Fraction & $\geq 60 \%$ & $\begin{array}{l}\text { I) Missing data } \\
\text { 2) Inconsistent data } \\
\text { 3) First ESRD treatment } \\
\text { given abroad }\end{array}$ & Process \\
\hline $\begin{array}{l}\text { 2) Early referral to } \\
\text { nephrology care }\end{array}$ & $\begin{array}{l}\text { First visit to specialist } \\
\text { nephrology department }>16 \\
\text { weeks before ESRD }\end{array}$ & $\begin{array}{l}\text { Incident patients } \\
\text { treated with dialysis } \\
\text { as their initial } \\
\text { treatment modality }\end{array}$ & Fraction & $\geq 70 \%$ & $\begin{array}{l}\text { I) Missing data } \\
\text { 2) Inconsistent data }\end{array}$ & Process \\
\hline $\begin{array}{l}\text { 3) Annual dialysis } \\
\text { mortality }\end{array}$ & $\begin{array}{l}\text { Number of dialysis patient } \\
\text { deaths divided by number of } \\
\text { dialysis patient-years } \\
\text { Adjustment for age and } \\
\text { comorbidity is planned }\end{array}$ & $\begin{array}{l}\text { Prevalent dialysis } \\
\text { patients }\end{array}$ & Rate & $\begin{array}{l}\leq 25 \% / \\
\text { year }\end{array}$ & $\begin{array}{l}\text { 1) Missing data } \\
\text { 2) Inconsistent data } \\
\text { 3) Dialysis treatment } \\
\text { periods outside } \\
\text { Denmark }\end{array}$ & Result \\
\hline $\begin{array}{l}\text { 4A) Transplantation: } \\
\text { I-year graft } \\
\text { survival }\end{array}$ & $\begin{array}{l}\text { Fraction of grafts functioning } \\
\text { after } 5 \text { years }\end{array}$ & $\begin{array}{l}\text { Incident patients } \\
\text { receiving first } \\
\text { transplant }\end{array}$ & Fraction & $\geq 90 \%$ & $\begin{array}{l}\text { I) Missing data } \\
\text { 2) Inconsistent data } \\
\text { 3) Emigration } \\
\text { 4) Transplant } \\
\text { operations } \\
\text { performed abroad }\end{array}$ & Result \\
\hline $\begin{array}{l}\text { 4B) Transplantation: } \\
\text { 5-year graft } \\
\text { survival }\end{array}$ & $\begin{array}{l}\text { Fraction of grafts functioning } \\
\text { after } 5 \text { years }\end{array}$ & $\begin{array}{l}\text { Incident patients } \\
\text { receiving first } \\
\text { transplant }\end{array}$ & Fraction & $\geq 75 \%$ & $\begin{array}{l}\text { I) Missing data } \\
\text { 2) Inconsistent data } \\
\text { 3) Emigration } \\
\text { 4) Transplant } \\
\text { operations } \\
\text { performed abroad }\end{array}$ & Result \\
\hline $\begin{array}{l}\text { 5A) Transplantation: } \\
\text { I-year patient } \\
\text { survival }\end{array}$ & $\begin{array}{l}\text { Fraction of grafts functioning } \\
\text { after I year } \\
\text { Adjustment for age and } \\
\text { comorbidity is planned }\end{array}$ & $\begin{array}{l}\text { Incident transplant } \\
\text { patients }\end{array}$ & Fraction & $\geq 96 \%$ & $\begin{array}{l}\text { I) Missing data } \\
\text { 2) Inconsistent data } \\
\text { 3) Emigration } \\
\text { 4) Transplant } \\
\text { operations } \\
\text { performed abroad }\end{array}$ & Result \\
\hline $\begin{array}{l}\text { 5B) Transplantation: } \\
\text { 5-year patient } \\
\text { survival }\end{array}$ & $\begin{array}{l}\text { Fraction of patients alive } \\
5 \text { years after transplantation } \\
\text { Adjustment for age and } \\
\text { comorbidity is planned }\end{array}$ & $\begin{array}{l}\text { Incident transplant } \\
\text { patients }\end{array}$ & Fraction & $\geq 85 \%$ & $\begin{array}{l}\text { I) Missing data } \\
\text { 2) Inconsistent data } \\
\text { 3) Emigration } \\
\text { 4) Transplant } \\
\text { operations } \\
\text { performed abroad }\end{array}$ & Result \\
\hline $\begin{array}{l}\text { 6) Peritonitis rate } \\
\text { (PD patients only) }\end{array}$ & $\begin{array}{l}\text { Number of peritonitis episodes } \\
\text { divided by number of PD } \\
\text { patient-years }\end{array}$ & $\begin{array}{l}\text { Incident transplant } \\
\text { patients }\end{array}$ & Rate & $\begin{array}{l}\leq 50 \% / \\
\text { year }\end{array}$ & $\begin{array}{l}\text { I) Missing data } \\
\text { 2) Inconsistent data }\end{array}$ & Result \\
\hline
\end{tabular}


Table 2 (Continued)

\begin{tabular}{|c|c|c|c|c|c|c|}
\hline Indicator & Definition & Population & Format & Standard & $\begin{array}{l}\text { Patient exclusion } \\
\text { criteria }\end{array}$ & $\begin{array}{l}\text { Indicator } \\
\text { type }\end{array}$ \\
\hline \multicolumn{7}{|c|}{ Biochemical quality indicators in dialysis patients: results for HD and PD patients are published separately } \\
\hline Hemoglobin & Fraction of patients $>6.5 \mathrm{mM}$ & $\begin{array}{l}\text { Prevalent dialysis } \\
\text { patients on } \\
\text { November I }\end{array}$ & Fraction & None & & Result \\
\hline $\begin{array}{l}\text { Transferrin } \\
\text { saturation }\end{array}$ & Fraction of patients $>20 \%$ & $\begin{array}{l}\text { Prevalent dialysis } \\
\text { patients on } \\
\text { November I }\end{array}$ & Fraction & None & & Result \\
\hline Ferritin & Fraction of patients $>200 \mathrm{mg} / \mathrm{L}$ & $\begin{array}{l}\text { Prevalent dialysis } \\
\text { patients on } \\
\text { November I }\end{array}$ & Fraction & None & & Result \\
\hline lonized calcium & $\begin{array}{l}\text { Fraction of patients } \\
\text { I) }<1.15 \mathrm{mM} \\
\text { 2) }>1.25 \mathrm{mM} \\
\text { 3) }>1.35 \mathrm{mM}\end{array}$ & $\begin{array}{l}\text { Prevalent dialysis } \\
\text { patients on } \\
\text { November I }\end{array}$ & Fraction & None & & Result \\
\hline Phosphate & Fraction of patients $>1.8 \mathrm{mM}$ & $\begin{array}{l}\text { Prevalent dialysis } \\
\text { patients on } \\
\text { November I }\end{array}$ & Fraction & None & & Result \\
\hline $\begin{array}{l}\text { Parathyroid } \\
\text { hormone }\end{array}$ & Fraction of patients $<30 \mathrm{pM}$ & $\begin{array}{l}\text { Prevalent dialysis } \\
\text { patients on } \\
\text { November I }\end{array}$ & Fraction & None & & Result \\
\hline Vitamin D & Fraction of patients $>75 \mathrm{nM}$ & $\begin{array}{l}\text { Prevalent dialysis } \\
\text { patients on } \\
\text { November I }\end{array}$ & Fraction & None & & Result \\
\hline
\end{tabular}

Abbreviations: PD, peritoneal dialysis; ESRD, end-stage renal disease; HD, hemodialysis.

Substantial improvements have been observed in several indicators. For instance, dialysis patient mortality has fallen since 1990 (Figure 2). RT results have improved since 1990; for example, for patients receiving a graft from a dead donor, 1-year mortality has fallen from $6 \%$ to $2 \%$ and 5 -year mortality from $18 \%$ to $9 \%$. One-year graft loss has fallen from $23 \%$ to $8 \%$ and 5 -year graft loss from $45 \%$ to $23 \%$. The fraction of early referral to nephrology care has risen from $63 \%$ to $76 \%$ since 2008 .

\section{Follow-up}

Follow-up of all patients continues until death, emigration, or other clinically relevant outcome. The treatment details of patients who received ESRD treatment before arrival in Denmark, or who are temporarily treated abroad, are reconstructed as exactly as possible using patient history and available medical records.

\section{Examples of research}

The DNR has revealed that Danish nephrology has a special place in international nephrology. Home HD is generally regarded as desirable due to better health and rehabilitation outcomes. Denmark has the highest prevalence of home HD in Europe. It is the first country to demonstrate a falling incidence of ESRD, in contrast to continuing increases in

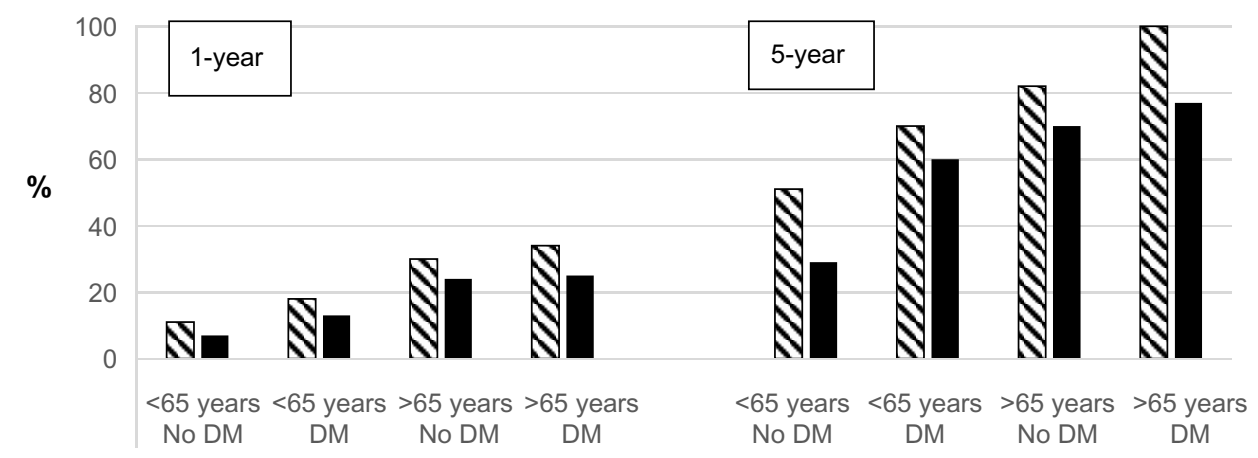

Figure 2 I- and 5-year dialysis mortality (\%) in Denmark during 1990-2014 grouped according to age ( $<65$ and $>65$ years) and renal diagnosis. Notes: No DM: other diagnoses; hatched bars: 1990-1994; solid bars: 2010-2014; 5-year: 2005-2009.

Abbreviation: DM, diabetic nephropathy. 
most other countries. The incidence among 60-69-yearolds has halved, presumably due to aggressive antihypertensive treatment and increased use of renin-angiotensin blockade. ${ }^{3}$ The DNR has been nominated as one of the seven best renal registries in the world, with full marks for accessibility, patient data availability, treatment data, and outcomes data. ${ }^{4}$

Forty-seven international peer-reviewed articles using DNR data have been published during the past 5 years (the list is available on DNS's home page www.nephrology.dk). In addition, the yearly report contains three special reports on various subjects, containing local epidemiological results of interest to DNS members (see Årsrapporter, www. nephrology.dk).

The existence of the civil personal registration number permits data to be merged with other national databases, eg, the DNPR, Scandiatransplant, the Danish Microbiology Database, and the Danish Cancer Registry.

Main research areas are the following:

1. European epidemiology. Articles range from general epidemiological reports ${ }^{5}$ to specific studies of rare diseases. ${ }^{6,7}$ DNR cooperates closely with the European Society of Paediatric Nephrology, which has resulted in a number of publications. ${ }^{8,9}$

2. Epidemiology in Denmark. DNR has documented regional differences in ESRD incidence in Denmark. ${ }^{10}$ Studies have shown that low birth weight is associated with earlier onset of ESRD in patients with polycystic disease, ${ }^{11}$ and that their prognosis has improved. ${ }^{12}$

3. ESRD is a complication associated with a number of diseases, and DNS supplies data for the study of these diseases, both nephrological, eg, lupus nephritis, ${ }^{13}$ and nonnephrological, eg, heart failure, ${ }^{14}$ intensive care patients, ${ }^{15,16}$ and HIV. ${ }^{16}$

\section{Administrative issues and funding}

The database became a clinical quality registry in 2000 , and was transferred to the Danish Clinical Registries in 2007, at which point the present quality indicator set was adopted. The database is administered by the DNS, which appoints the board of directors. Permission from the Danish Data Protection Agency has been obtained (Journal number 2012-58-0017).

All data registrations have been computerized since 1990, initially using the Nephrobase computer program. A new online computer platform, Topica DNSL, was introduced, hosted by the information technology (IT) company CSC Scandihealth, Skejby, Denmark. The Registry Support
Centre of Epidemiology and Biostatistics (South), Odense University Hospital, is responsible for data validation, statistical analyses, and the production of the yearly indicator report. The database is $100 \%$ financed by the Danish Clinical Registries, which is owned by Danish Regions.

\section{Conclusion}

The database fulfills its stated aims of providing high-quality data for national clinical quality control, international epidemiology, and scientific research. At present, objective patient observational data, and patient-reported outcome measures and medical treatment are not available. The increasing use of electronic medical records is expected to permit inclusion of these data.

\section{Acknowledgments}

This paper was funded by the Program for Clinical Research Infrastructure (PROCRIN) established by the Lundbeck Foundation and the Novo Nordisk Foundation and administered by the Danish Regions.

\section{Disclosure}

The author is the director of the DNR and receives an honorary from Danish Regions for this task. The author reports no other conflicts of interest in this work.

\section{References}

1. Hommel K, Rasmussen S, Madsen M, Kamper AL. The Danish Registry on Regular Dialysis and Transplantation: completeness and validity of incident patient registration. Nephrol Dial Transplant. 2010;25(3):947-951.

2. Charlson ME, Pompei P, Ales KL, MacKenzie CR. A new method of classifying prognostic comorbidity in longitudinal studies: development and validation. J Chronic Dis. 1987;40(5):373-383.

3. Heaf JG, Wehberg S. Reduced incidence of end stage renal disease among the elderly in Denmark: an observational study. BMC Nephrol. 2012;13:131

4. Liu FX, Rutherford P, Smoyer-Tomic K, Prichard S, Laplante S. A global overview of renal registries: a systematic review. BMC Nephrol. 2015;16:31.

5. Pippias M, Stel VS, Abad Diez JM et al. Renal replacement therapy in Europe: a summary of the 2012 ERA-EDTA Registry Annual Report. Clin Kidney J. 2015;8(3):248-261.

6. Temme J, Kramer A, Jager KJ et al. Outcomes of male patients with Alport syndrome undergoing renal replacement therapy. Clin J Am Soc Nephrol. 2012;7(12):1969-1976.

7. Wuhl E, van Stralen KJ, Wanner C et al. Renal replacement therapy for rare diseases affecting the kidney: an analysis of the ERA-EDTA Registry. Nephrol Dial Transplant. 2014;29(Supp1 4):iv1-iv8.

8. Harambat J, van Stralen KJ, Verrina E, Groothoff JW, Schaefer F, Jager KJ; ESPN/ERA-EDTA Registry. Likelihood of children with end-stage kidney disease in Europe to live with a functioning kidney transplant is mainly explained by nonmedical factors. Pediatr Nephrol. 2014;29(3):453-459.

9. Harambat J, Bonthuis M, van Stralen KJ et al. Adult height in patients with advanced CKD requiring renal replacement therapy during childhood. Clin J Am Soc Nephrol. 2014;9(1):92-99. 
10. Hommel K, Rasmussen S, Kamper AL, Madsen M. Regional and social inequalities in chronic renal replacement therapy in Denmark. Nephrol Dial Transplant. 2010;25(8):2624-2632.

11. Orskov B, Christensen KB, Feldt-Rasmussen B, Strandgaard S. Low birth weight is associated with earlier onset of end-stage renal disease in Danish patients with autosomal dominant polycystic kidney disease. Kidney Int. 2012;81(9):919-924.

12. Orskov B, Romming Sørensen V, Feldt-Rasmussen B, Strandgaard S. Improved prognosis in patients with autosomal dominant polycystic kidney disease in Denmark. Clin J Am Soc Nephrol. 2010;5(11):2034-2039.

13. Faurschou M, Dreyer L, Kamper AL, Starklint H, Jacobsen S. Longterm mortality and renal outcome in a cohort of 100 patients with lupus nephritis. Arthritis Care Res (Hoboken). 2010;62(6):873-880.
14. Bosselmann $\mathrm{H}$, Gislason $\mathrm{G}$, Gustafsson $\mathrm{F}$ et al. Incidence and predictors of end-stage renal disease in outpatients with systolic heart failure. Circ Heart Fail. 2013;6(6):1124-1131.

15. Gammelager H, Christiansen CF, Johansen MB, Tonnesen E, Jespersen B, Sørensen HT. Five-year risk of end-stage renal disease among intensive care patients surviving dialysis-requiring acute kidney injury: a nationwide cohort study. Crit Care. 2013;17(4):R145.

16. Rasch MG, Engsig FN, Feldt-Rasmussen B, et al. Renal function and incidence of chronic kidney disease in HIV patients: a Danish cohort study. Scand J Infect Dis. 2012;44(9):689-696.
Clinical Epidemiology

\section{Publish your work in this journal}

Clinical Epidemiology is an international, peer-reviewed, open access, online journal focusing on disease and drug epidemiology, identification of risk factors and screening procedures to develop optimal preventative initiatives and programs. Specific topics include: diagnosis, prognosis, treatment, screening, prevention, risk factor modification,

Submit your manuscript here: http://www.dovepress.com/clinical-epidemiology-journal

\section{Dovepress}

systematic reviews, risk \& safety of medical interventions, epidemiology \& biostatistical methods, and evaluation of guidelines, translational medicine, health policies \& economic evaluations. The manuscript management system is completely online and includes a very quick and fair peer-review system, which is all easy to use. 